\title{
Environmentally-assisted Fatigue Crack Growth in AA7050-T73511 Al Alloy and AA2050-T84 Al-Cu-Li Alloy
}

\author{
Jéferson Aparecido Moreto * , Fernando Antônio Paschoal Júnior ${ }^{b}$, Carla Isabel Santos Macielc, \\ Luis Henrique Camargo Bonazzic, José Francisco Leonelli Júniorc, \\ Cassius Olívio Figueiredo Terra Ruchert ${ }^{c}$, Waldek Wladimir Bose Filho ${ }^{c}$
}

\author{
${ }^{a}$ Departamento de Pós-graduação - DPPG, Instituto Federal Goiano - IF Goiano, \\ Campus Rio Verde, Rod. Sul Goiana, Km 01, Zona Rural, CEP 75901-970, Rio Verde, GO, Brazil \\ ${ }^{b}$ Empresa Brasileira de Aeronáutica - EMBRAER S.A, Unidade Agrícola, Botucatu, SP, Brazil \\ ${ }^{c}$ Departamento de Engenharia de Materiais, Escola de Engenharia de São Carlos, Universidade de São \\ Paulo - USP, Av. Trabalhador São Carlense, 400, CEP 13566-590, São Carlos, SP, Brazil
}

Received: August 10, 2015; Revised: October 5, 2015

\begin{abstract}
The aim of this study was to evaluate and compare the effect of low temperature and saline environment on the fatigue crack growth behavior of the AA7050-T7451 Al alloy and the recently developed AA2050-T Al-Cu-Li alloy. Fatigue at room and low temperature and corrosion-fatigue tests were carried out using an applied stress ratio (R) of $0.1,15 \mathrm{~Hz}$ frequency (air at RT and $-54^{\circ} \mathrm{C}$ ) and $1 \mathrm{~Hz}$ frequency (seawater fog) using a sinusoidal wave form. In the near-threshold region, in air and at RT it was found a $\Delta \mathrm{K}_{\text {th }}=2.9 \mathrm{MPa} \cdot \mathrm{m}^{1 / 2}$ for AA2050-T84, in saline environment this value increased to $\Delta \mathrm{K}_{\mathrm{th}}=4.9 \mathrm{MPa} \cdot \mathrm{m}^{1 / 2}$, due to closure effect through wedge effect by the corrosion products. At the beginning of the Paris-Erdogan region, the crack closure effect was not present for the AA7050-T7451, but persisted for the AA2050 Al-li alloy. It was observed that both alloys were equally affected by temperature reduction. When the saline environment is considered it was observed that the AA7050-T7451 presents lower m value (2.6) than the one for AA2050-T84 (3.4), meaning a lower FCG rate variation with $\Delta \mathrm{K}$, however it presented the highest $\mathrm{C}$ value, as a consequence the worst FCG behavior.
\end{abstract}

Keywords: Al-Li alloys, low temperature, corrosion-fatigue, seawater fog

\section{Introduction}

Aluminum alloys are produced as castings, sheets, plates, bars, rods and forgings, as well as, applied in different industrial sectors, including the aerospace industry ${ }^{1}$. The aircraft industry is on the constant lookout for improved materials that offer benefits in terms of performance, weight and cost savings.

Aluminum alloys effectively reduce the weight of transportation vehicles, and their applications are expanding continually. The aforementioned factors, plus the fact that some of these alloys can be formed in a soft condition and heat-treated to a temper comparable to that of structural steel, make them very attractive for aircraft parts.

The aerospace industry has recently shown renewed interest in aluminum-lithium (Al-Li) alloys. Since they discovery, in the mid-1950s, that adding lithium to aluminum alloys results in materials with reduced weight and high specific modulus (E/ $/$ ), aluminum manufacturers have been diligent in their efforts to fabricate a commercial alloy. The low ductility and fracture toughness of the first generation of Al-Li alloys led to a significant increase in research focusing on these alloys ${ }^{2,3}$. The second generation of Al-Li alloys are characterized by strong anisotropy, while the third generation of Al-Li-Zr and Al-Mg-Li-Zr alloys are more resistant to

*e-mail: jeferson_moreto@yahoo.com.br stress corrosion cracking (SCC) than more conventional alloys subjected to the same heat treatments ${ }^{4}$. Pronounced slip reversibility and tortuous morphology of the crack path may result in a material with higher tolerance to damage than that of conventional aluminum alloys. Factors that improve resistance to fatigue crack propagation often tend to have a detrimental influence on fatigue crack initiation. The fatigue strength of aluminum alloys is lower in aggressive media such as seawater and saline solutions than in air, particularly when tested in the high cycle region ${ }^{5}$.

The interaction of corrosion and fatigue effects on the mechanical properties of aluminum alloys are major issues in the in-service life assessment of aircraft structures and in the management of aging air fleets ${ }^{6}$. Corrosion-fatigue (CF) is an important and very complex failure mode that take place in high-performance structural metals operating in an aggressive environment. CF affects nuclear power systems, steam and gas turbines, aircraft, marine structures, pipelines, and bridges. $\mathrm{CF}$, which is defined as the sequential stages of metal damage that evolve with accumulated cyclic loads in environments that are more aggressive than inert or benign environments, is the result of the interaction of irreversible cyclic plastic deformation with localized chemical 
or electrochemical reactions. Environment-enhanced fatigue is a modern term; however, the term CF is traditionally used when referring specifically to electrochemical environments. Mechanical fatigue experiments and analyses described in recent textbooks ${ }^{7,8}$ provide the basis for understanding the corrosion-fatigue phenomena 9 .

High strength age-hardenable aluminum alloys, such as $2 \mathrm{XXX}$ and $7 \mathrm{XXX}$ series, have been most widely used structural materials in aeronautical applications, based on their good mechanical properties and low densities ${ }^{10}$. However, 2XXX and 7XXX series aluminum alloys used in aircraft industry are particularly sensitive to corrosion process ${ }^{11}$.

The 2XXX series are used in structural components due to their high toughness and good fatigue strength. These alloys generally have a desirable combination of strength, damage tolerance, formability and density that is suitable for many engineering applications. They are especially sensitive to aqueous media containing chloride ions, because such media favor pitting corrosion, generating stress concentrators that reduce their fatigue life ${ }^{12,13} \cdot 7 \mathrm{XXX}$ series aluminum alloys are widely used in the aircraft industry due to their high strength to density ratio ${ }^{14}$.

The AA7050-T7451 is the premier choice for aerospace applications requiring the best combination of strength, stress corrosion cracking (SCC) resistance and toughness, which are superior to that provided by conventional high strength alloys like AA7075-T6 ${ }^{13}$. AA7050-T7451 was developed specifically for an optimum combination of the above properties in thick sections by reducing the quench sensitivity.

The AA2050-T84 is a part of the 2XXX series aluminum alloys newly developed for application in the aircraft industry. These alloys are specifically designed to have good mechanical properties in order to be used as structural components in aircraft. This alloy contains lithium as an alloying element to reduce density and increase the Young's modulus and thus to save weight. In fact, the addition of $1 \mathrm{wt} \%$ lithium to aluminium reduces the density by $3 \%$ and increases the elastic modulus by about $6 \%{ }^{13}$. The AA2524-T3 is a Al-Cu-Mg alloy intended for fuselage skin replacements, presenting a superior fracture toughness and resistance to fatigue crack growth. In what concerns the AA7081-T73511, its applications may include wing components or fuselage frames

The aim of this work was to evaluate the fatigue crack growth behavior of the AA2050-T84 (Al-Cu-Li), comparing the results considering the effect of low temperature and a saline environment with the ones for the AA7050-T7451 regularly employed in aircraft structural application.

\section{Experimental Procedures}

\subsection{Materials}

In the present investigation, two high strength $\mathrm{Al}$ alloys were provided as rolled plates, named as AA7050-T7451 (Al-Zn-Mg-Cu-Mg alloy - $25.4 \mathrm{~mm}$ thick), and the recently developed AA2050-T84 (Al-Cu-Li alloy - $50 \mathrm{~mm}$ thick). Their nominal chemical compositions are presented in Table 1.

\subsection{Fatigue crack growth tests}

Fatigue crack growth (FCG) tests were carried out following the ASTM E647-11 standard ${ }^{14}$, in a $100 \mathrm{kN}$ capacity MTS servo-hydraulic testing system, under load control, sinusoidal waveform, frequencies of $15 \mathrm{~Hz}$ (air) and $1 \mathrm{~Hz}$ (saline environment), stress ratio, $\mathrm{R}=0.1$, in air at room (RT) and low temperature $\left(-54{ }^{\circ} \mathrm{C}\right.$ ), and in seawater fog (water solution with $3,5 \mathrm{wt} \% \mathrm{NaCl}$ ). Precracking was conducted in air, at $15 \mathrm{~Hz}$ frequency and to a crack size of $1 \mathrm{~mm}$ from the notch. T-L compact tension C(T) specimen were used, with width, $\mathrm{W}=50 \mathrm{~mm}$ and a thickness, $\mathrm{B}=12.5 \mathrm{~mm}$. Figure 1 shows the size and geometry of the $\mathrm{C}(\mathrm{T})$ specimens. The low temperature fatigue crack growth tests were carried out inside of a cooling chamber, after a soaking time of $30 \mathrm{~min}$ at the chosen temperature.

In seawater fog at RT, the tests followed similar procedure applied in air. A special acrylic cell and a reservoir for fog generation were specially fabricated, see Figure 2. In this setup, the fog circulated through the cell, supplied by the external reservoir and then expelled to the external environment, detail may be found elsewhere ${ }^{15}$.

Crack length was measured using elastic compliance technique as recommended by the ASTM E647-11 ${ }^{14}$, with the clip gage mounted at notch mouth, providing the crack-mouth-opening displacement (CMOD). The salt solution concentration $(3.5 \mathrm{wt} \%$ of $\mathrm{NaCl})$ and $\mathrm{pH}(7.2)$ in the reservoir to generate the fog, were controlled during the test and kept constant.

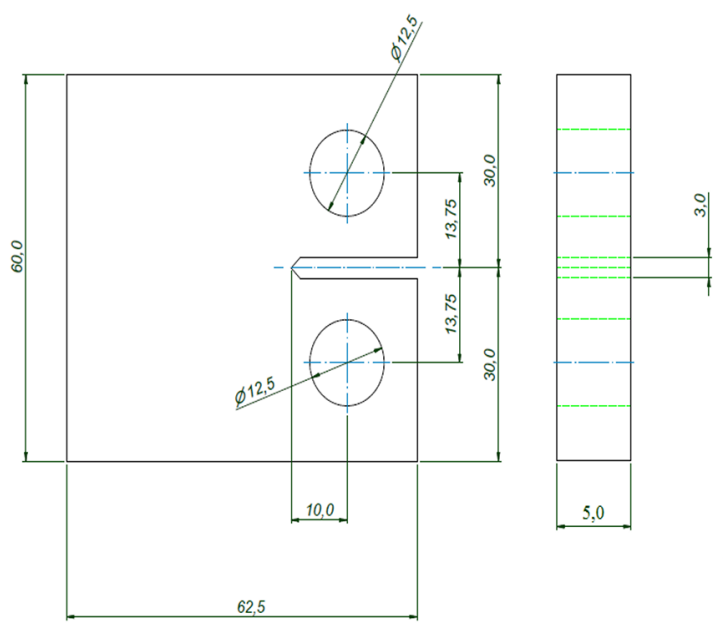

Figure 1. Size and geometry of the $\mathrm{C}(\mathrm{T})$ specimens (dimensions in millimeter). ASTM E647-11 ${ }^{14}$.

Table 1. Nominal chemical composition of the $\mathrm{Al}$ alloys (wt\%).

\begin{tabular}{cccccccccccc}
\hline Alloy & $\mathbf{C u}$ & $\mathbf{M g}$ & $\mathbf{M n}$ & $\mathbf{Z n}$ & $\mathbf{F e}$ & $\mathbf{T i}$ & $\mathbf{S i}$ & $\mathbf{C r}$ & $\mathbf{L i}$ & $\mathbf{Z r}$ & $\mathbf{A l}$ \\
\hline 2050-T84 & 3.54 & 0.31 & 0.37 & 0.02 & 0.06 & 0.03 & 0.03 & $20^{*}$ & 0.87 & 0.08 & Base \\
$7050-\mathrm{T} 7451$ & 2.25 & 1.896 & 0.01 & 6.02 & 0.05 & 0.03 & 0.04 & 0.01 & ND & 0.10 & Base \\
\hline
\end{tabular}

ND: Not determined. * - ppm. 


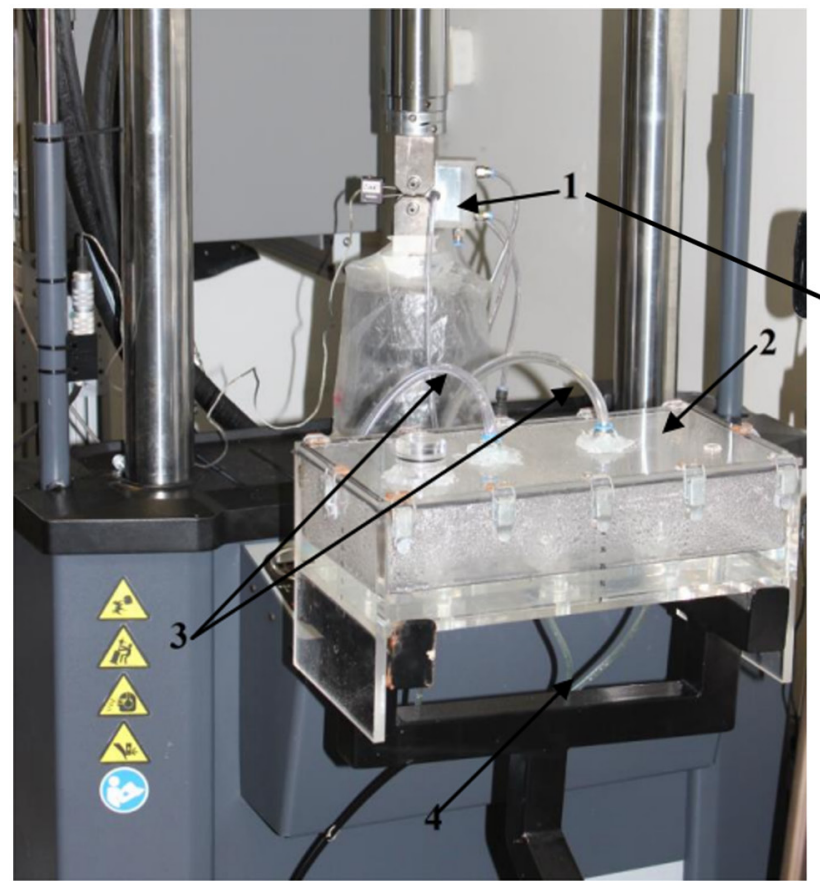

(a)

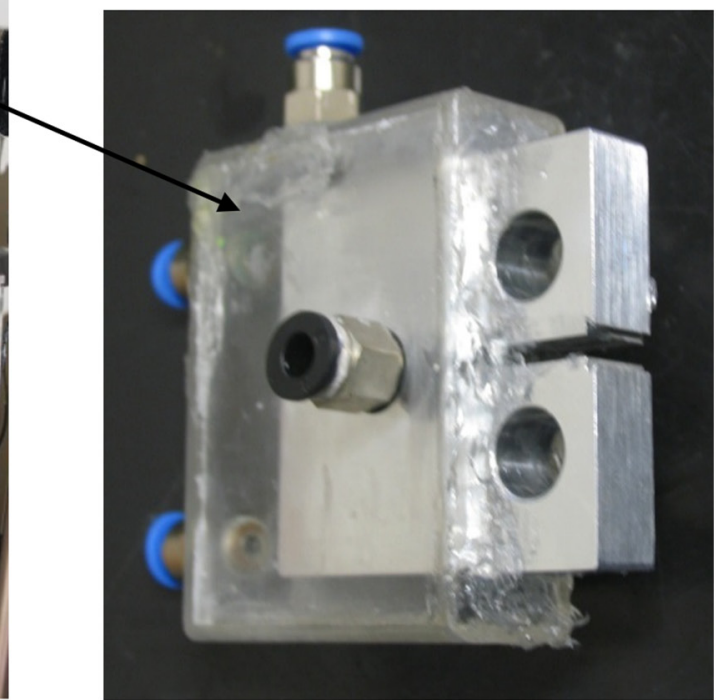

(b)

Figure 2. (a) Settings for FCG in saline fog. (1) Specimen mounted for testing. (2) Reservoir for fog generation. (3) Fog outlet towards the acrylic cell. (4) Compressed air to enter the nebulizers inside the reservoir. (b) Detail of the specimen mounted inside the fog cell ${ }^{15}$.

From the fatigue crack growth tests, the coefficients C and $\mathrm{m}$, from the Paris/Erdogan equation, were evaluated for all tests conditions. The fatigue threshold, $\Delta \mathrm{K}_{\text {th }}$ was only evaluated for the new AA2050-T84 Al alloy considering air and saline fog environments. In this case, as recommended by the ASTM E647-11 ${ }^{14}$, the tests were carried out in K control, with the normalized K-gradient of approximately $-0.07 \mathrm{~mm}^{-1}$. Otherwise, the FCG tests were carried out in load control.

\section{Results and Discussions}

The fatigue crack growth rates (FCGRs), da/dN, as function of the variation of the stress intensity factor, $\Delta K$, measured in air at room and $-54{ }^{\circ} \mathrm{C}$ temperatures, and in seawater fog are presented in Figures 3 to 5 .

Generally, the results show that independent of the environment, the FCG rates are quite similar for the two alloys studied here. There is a light difference when they were tested in seawater fog at the beginning of the linear region (Paris region near-threshold), where the AA2050-T84 presented a lower FCG rate than the AA7050-T7451.

In the threshold region, in air and at RT, were found values of $\Delta \mathrm{K}_{\text {th }}$ of 3.4 and 2.9 MPa.m ${ }^{1 / 2}$ for the AA7050-T7451 and AA2050-T84, respectively. In saline environment and at low $\Delta K$ values, the corrosive effect becomes the most influential variable, since the environment overrides the loading influence, increasing or reducing crack growth rate. In this study, in the saline environment, the value of $\Delta \mathrm{K}_{\text {th }}$ was only evaluated for the new AA2050-T84 (Al-Cu-Li) and it was observed that this value increased to $\Delta \mathrm{K}_{\mathrm{th}}=4.9 \mathrm{MPa} \cdot \mathrm{m}^{1 / 2}$. However, from

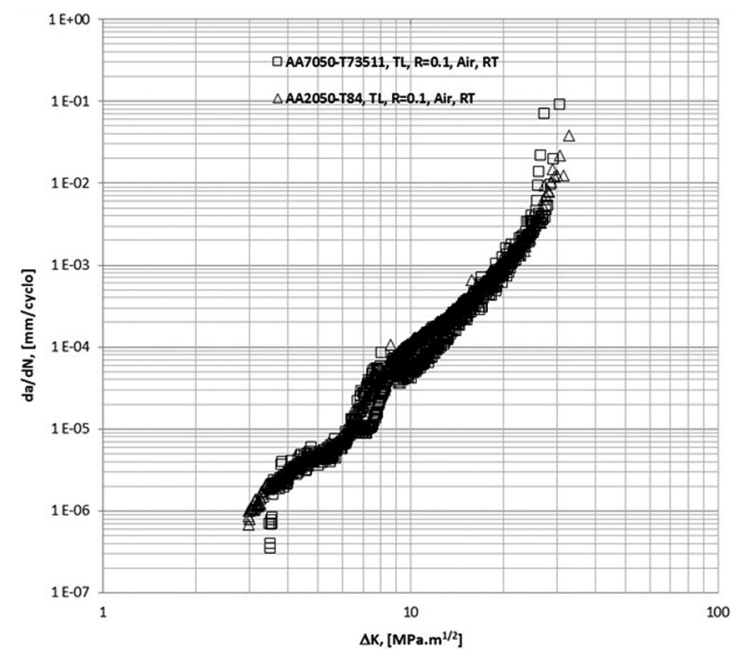

Figure 3. da/dN x $\Delta \mathrm{K}$ curves for the AA2050-T84 Al-Li and AA7050-T7451 Al alloys tested in air, $\mathrm{R}=0.1,15 \mathrm{~Hz}$ frequency and room temperature.

the results from Maciel ${ }^{15}$, it was observed that the effective value of the stress intensity range, $\Delta \mathrm{K}_{\text {thef }}=3.0 \mathrm{MPa} \cdot \mathrm{m}^{1 / 2}$ is quite similar to the one in air.

The explanation for this increased value of $\Delta \mathrm{K}_{\mathrm{th}}$, in saline environment, lies in the fact that in near-threshold, crack closure is quite important and the corrosion-products have induced wedge effect. Although the crack is fully opened at the maximum stress intensity. $\mathrm{K}_{\max }$. corrosion products formed within the crack lead to earlier contact between 


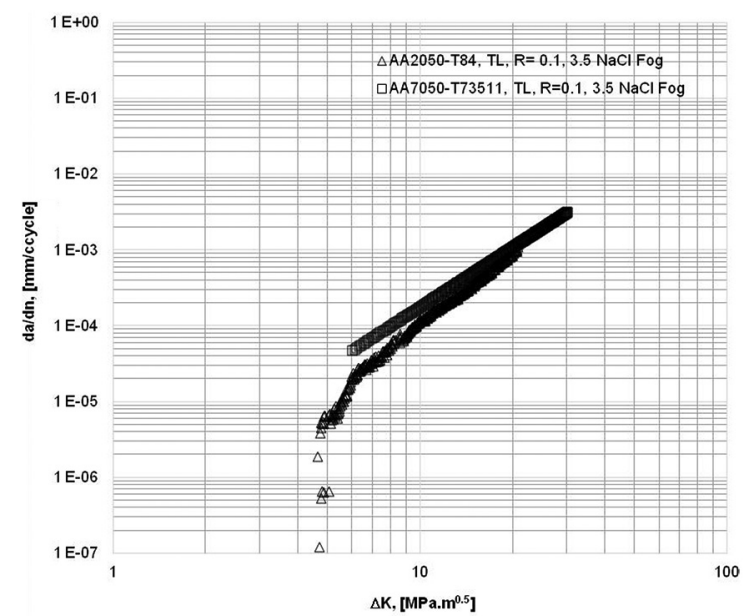

Figure 4. da/dN x $\Delta \mathrm{K}$ curves for the AA2050-T84 Al-Li and AA7050-T7451 Al alloys tested in air, $\mathrm{R}=0.1,15 \mathrm{~Hz}$ frequency, saline environment (3.5 wt $\% \mathrm{NaCl})$.

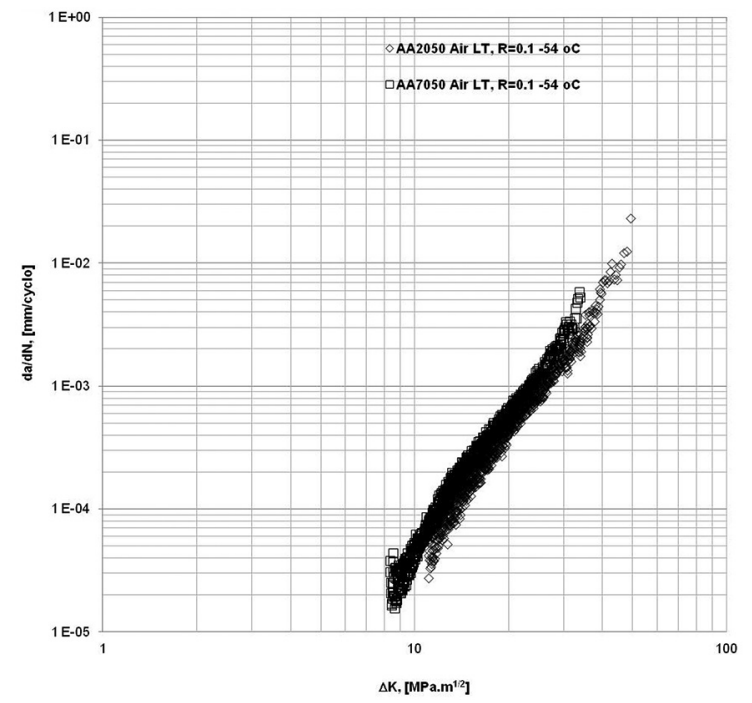

Figure 5. da/dN x $\Delta \mathrm{K}$ curves for the AA2050-T84 Al-Li and AA7050-T7451 Al alloys tested in air, $\mathrm{R}=0.1,15 \mathrm{~Hz}$ frequency at $-54{ }^{\circ} \mathrm{C}$.

crack surfaces, thereby raising the minimum value of the stress intensity factor at which the crack closes, $\mathrm{K}_{\min }=\mathrm{K}_{\mathrm{cl}}$. see Figure 6.

At low $\Delta \mathrm{K}$ values, close to the threshold regime, the corrosion-fatigue behavior of AA2050-T84 was quite similar to that obtained in air at RT. In both case the values of $\mathrm{da} / \mathrm{dN}$ was found to be approximately $1 \mathrm{E}-5 \mathrm{~mm} / \mathrm{cycle}$ for a $\Delta \mathrm{K}=6 \mathrm{MPa} \cdot \mathrm{m}^{1 / 2}$. As was observed by $\mathrm{Maciel}^{15}$, the effect of crack closure on the FCG rate in this region was quite intense in this alloy in presence of the saline fog. It is assumed that it may have persisted at the beginning of the Paris-Erdogan regime, neutralizing the environment effect (salt fog effect), i. e., causing reduction in the FCG rate by wedging effect. When low values of $\Delta \mathrm{K}$ are considered for the AA7050-T7451 alloy, it is observed a different FCG
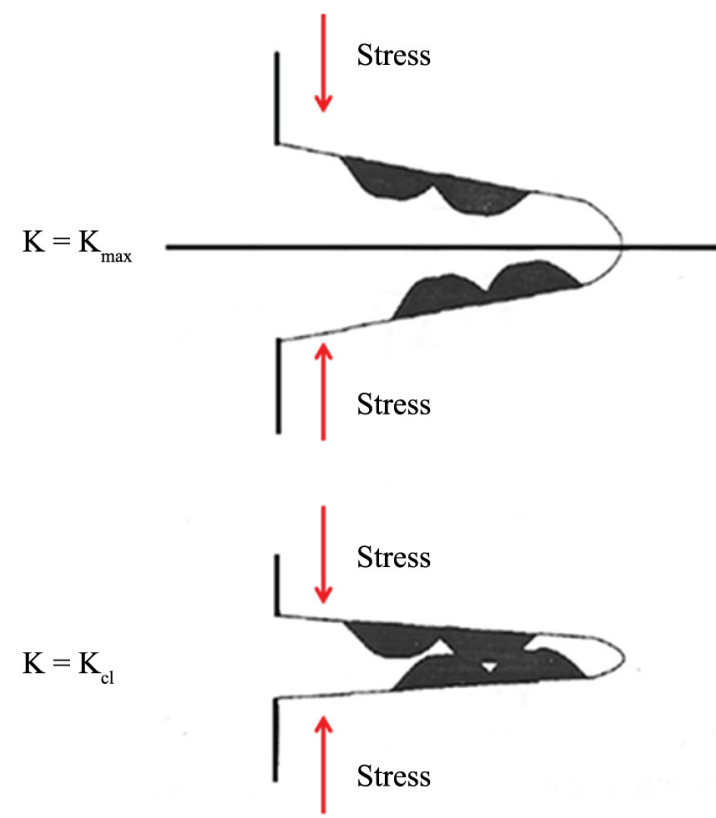

Figure 6. Schematic illustration of the wedging effect mechanism induced by corrosion products. Figure adapted from Komai ${ }^{16}$.

behavior when tested in air and seawater fog environments. As observed by Vasudévan \& Suresh ${ }^{17}$ the extent of crack closure due to corrosion debris in aluminum alloys is strongly dependent on the composition and aging treatment, and this may be the case when comparing FCG for AA7050-T7451 and AA2050-T84 close to the threshold regime.

In the Paris-Erdogan region, the results show a slightly increase in the FCG rate by the chloride environment for both alloys, AA7050-T7451 and AA2050-T84. As expected, when $\Delta \mathrm{K}$ increased during test, this effect gradually was reduced, since the mechanical effect of loading in the FCG micromechanism start to be predominant. For $\Delta K$ values larger than $17 \mathrm{MPa} . \mathrm{m}^{1 / 2}$, both alloys present similar FCG rate in air and in seawater conditions. The corrosion-fatigue behavior dependence on $\Delta \mathrm{K}$ can be explained based on the following reasons: at higher $\Delta \mathrm{K}$ values, the environment has less time to interact with the propagating front and the FCG process occurs by purely mechanical action as the case in air.

Table 2 presents the values of the material's constants for the Paris-Erdogan regime and Figure 7 presents a summary of these equations for FCG behavior considering both $\mathrm{Al}$ alloy and environments. The Paris' law parameters are empirical constants that are dependent on the testing conditions, and they may be dependent on each other, making the FCG analysis based on them a quite complex task. Higher m values, indicates higher increments in FCG rate with increasing $\Delta \mathrm{K}$. For similar $\mathrm{m}$ values, higher $\mathrm{C}$ values indicates higher $\mathrm{FCG}$ rates. Considering the air-RT environment, both alloys present close $\mathrm{m}$ (3.1 and 3.4) and $\mathrm{C}$ values (8.87E-08 to 3.63E-08). In air $-54{ }^{\circ} \mathrm{C}$, the $\mathrm{Al}$ alloys presents quite similar values of $\mathrm{m}$ (4.2) and C (3.00E-09 to 3.4E-09) proving that their FCG behavior were equally affected by temperature reduction. When the saline environment is considered it was observed that the AA7050-T7451 presents lower m value (2.6) than 
Table 2. Material's constant $\mathrm{C}$ and $\mathrm{m}$ for the Paris-Erdogan equation.

\begin{tabular}{cccccc}
\hline Alloy & Environment & m & C & Paris & R $^{2}$ \\
\hline \multirow{3}{*}{ AA7050-T7451 } & Air - RT & 3.14 & $8.87 \mathrm{E}-08$ & $\mathrm{da} / \mathrm{dN}=8.87-08(\Delta \mathrm{K})^{3.14}$ & 0.992 \\
& $3.5 \mathrm{wt} \%$ Fog & 2.61 & $4.45 \mathrm{E}-07$ & $\mathrm{da} / \mathrm{dN}=4.45-07(\Delta \mathrm{K})^{2.61}$ & 0.987 \\
& Air $-54^{\circ} \mathrm{C}$ & 4.17 & $3.37 \mathrm{E}-09$ & $\mathrm{da} / \mathrm{dN}=3.37 \mathrm{E}-09(\Delta \mathrm{K})^{4.17}$ & 0.997 \\
\hline \multirow{2}{*}{ AA2050-T84 } & Air $-\mathrm{RT}$ & 3.42 & $3.63 \mathrm{E}-08$ & $\mathrm{da} / \mathrm{dN}=3.63-08(\Delta \mathrm{K})^{3.42}$ & 0.993 \\
& $3.5 \mathrm{wt} \%$ Fog & 3.37 & $4.25 \mathrm{E}-08$ & $\mathrm{da} / \mathrm{dN}=4.25-08(\Delta \mathrm{K})^{3.37}$ & 0.983 \\
& Air $-54^{\circ} \mathrm{C}$ & 4.15 & $3.00 \mathrm{E}-09$ & $\mathrm{da} / \mathrm{dN}=3.00-09(\Delta \mathrm{K})^{4.15}$ & 0.976 \\
\hline
\end{tabular}

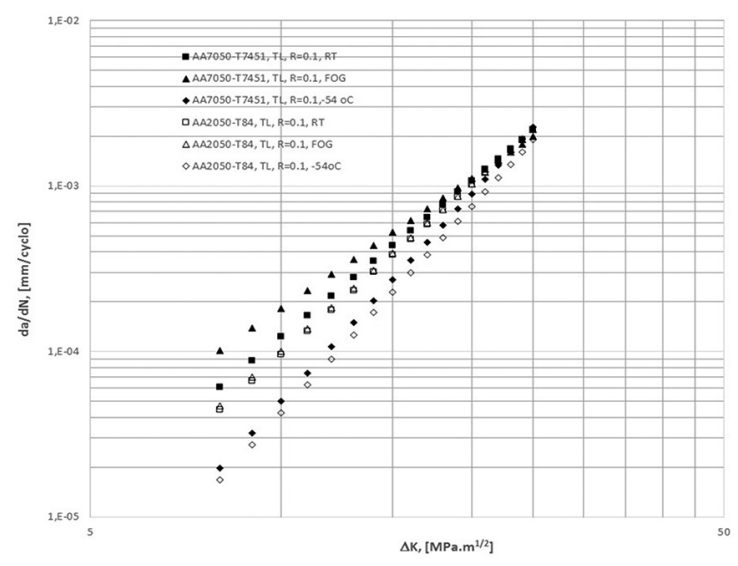

Figure 7. Summary of plots for the equations presented in Table 2 for FCG behavior considering both $\mathrm{Al}$ alloy and environments.

the AA2050-T84 (3.4), meaning a lower FCG rate variation with $\Delta \mathrm{K}$, however it presents the highest $\mathrm{C}$ value, as a consequence it presented the worst FCG behavior. At lower $\Delta \mathrm{K}$ values, near-threshold regime, and in the presence of chloride ions two mechanisms may be acting.

\subsection{Stress-assisted dissolution}

The protective film formed at crack tips is ruptured by the applied cyclic stresses, whereby dissolution of exposed metal is accelerated. The repassivation reaction competes with the dissolution, and when the rate of the former exceeds that of the latter, stress-assisted dissolution stops ${ }^{18}$. Figure 8 shows the stress-assisted dissolution mechanism near the crack tip.

\subsection{Hydrogen embrittlement}

The effects of environment in the intermediate region (Paris region) of the FCG curve have shown that in aluminum alloys, environmentally induced variations in FCG rates result primarily from hydrogen embrittlement mechanisms due to the presence of a moisture in the medium ${ }^{18}$. Recent surface chemistry studies in aluminum alloys suggest that the hydrogen embrittlement process resulting from moisture is rate-limited by the transport of water vapor to the crack tip and the surface reaction kinetics. Hydrogen embrittlement occurs in a number of forms, but the common features are an applied tensile stress and hydrogen dissolved in the metal. Hydrogen embrittlement has been proposed to account for the enhanced FCG rate in corrosive environments for aluminum alloys. According to Lin \& Yang ${ }^{13}$ corrosion fatigue and surface chemistry studies in high strength aluminum alloys suggest that hydrogen produced by the reaction of water

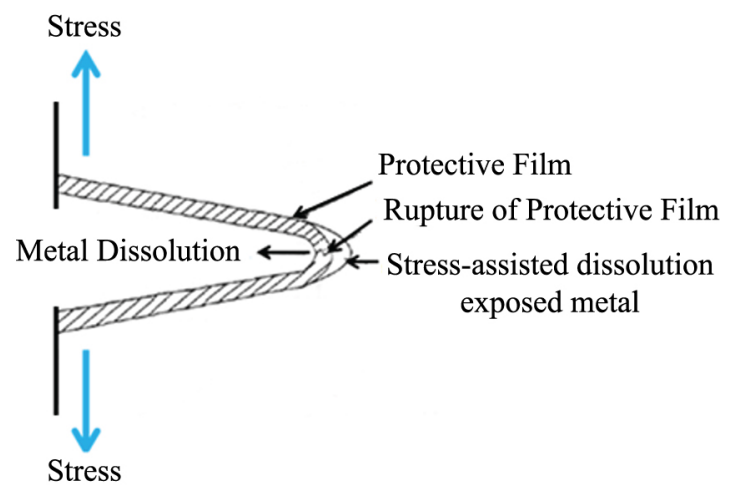

Figure 8. Schematic illustration of the stress-assisted dissolution mechanism near the crack tip. Figure adapted from Komai ${ }^{16}$ and Ford ${ }^{18}$.

vapor with the freshly formed fracture surface is responsible for an embrittlement process by an active path dissolution mechanism. Ford ${ }^{18}$ presented a quantitative verification of the slip dissolution and hydrogen embrittlement mechanisms, and concluded that the environment controlled component for A1-Mg alloy is due to the slip dissolution mechanism. Menan \& Henaff ${ }^{6}$ studied the influence of frequency and exposure to a saline solution on the corrosion-fatigue behavior of the AA2024 Al alloy, and concluded that the possible mechanisms that govern the corrosion-fatigue behavior of the AA2024 Al alloy must be discussed in terms of a competition between passivation and anodic dissolution and/or hydrogen embrittlement.

Considering the effect of low temperature and air in the FCG rate, it was found that in the Paris-Erdogan regime, FCG rate was lower at lower $\Delta \mathrm{K}$ values, and this effect was associated to an increase in the yield strength at $-54{ }^{\circ} \mathrm{C}$ and reduction in the effect of the environment.

A similar trend was found by Albelkis ${ }^{19}$, studying the effect of temperature on the FCG of AA2024 and AA 7475 Al alloys. It has been verified that materials with no ductile - brittle temperature transition and with significant increase in the yield strength when tensile test temperature is lowered, the FCG rate may be reduced due to more resistance to plastic deformation at the crack tip (reduction in dislocation mobility $)^{20,21}$. Table 3 presents the results from the tensile tests carried out at RT and $-54{ }^{\circ} \mathrm{C}$. It is observed that when the temperature was lowered that was an increase in $\sigma_{0.2 \%}$ of $11 \%$ and $14 \%$, for the AA2050-T84 and AA7050-T7451, respectively. Although, the increasing in yield strength was not very significant, it may has contributed for the reduction 
Table 3. Tensile properties.

\begin{tabular}{|c|c|c|c|c|c|c|c|c|}
\hline \multirow[b]{2}{*}{ Alloy } & \multicolumn{4}{|c|}{$\mathrm{RT}=23^{\circ} \mathrm{C}$} & \multicolumn{4}{|c|}{$-54^{\circ} \mathrm{C}$} \\
\hline & $\begin{array}{c}\sigma_{\text {UTS }} \\
(\mathrm{MPa})\end{array}$ & $\begin{array}{c}\sigma_{0.2 \%} \\
\text { (MPa) }\end{array}$ & $\begin{array}{c}\text { EL } \\
{[\%]}\end{array}$ & $\begin{array}{c}\text { AR } \\
{[\%]}\end{array}$ & $\begin{array}{c}\sigma_{\text {UTS }} \\
(\mathrm{MPa})\end{array}$ & $\begin{array}{c}\sigma_{0.2 \%} \\
(\mathrm{MPa})\end{array}$ & $\begin{array}{c}\text { EL } \\
{[\%]}\end{array}$ & $\begin{array}{l}\text { AR } \\
{[\%]}\end{array}$ \\
\hline AA2050-T84 & 511 & 477 & 12 & 33 & 566 & 530 & 12 & 31 \\
\hline AA7050-T7451 & 533 & 459 & 9.7 & 35.1 & 589 & 524 & 9.5 & 33 \\
\hline
\end{tabular}

in the FCG rate, added to the low temperature effect on the activity of the environment at the crack front. At lower temperature the effect of air moisture are reduced ${ }^{2}$. In fact, in this study this appears to be the major effect on reducing FCG rate, since at higher $\triangle \mathrm{K}$ values FCP rates are similar to the one at RT and air environment. Therefore, the main effect is the one from mechanical loading (fatigue striation that is dependent on local plastic deformation).

\section{Conclusions}

The AA2050-T84 with Li addition, was specifically designed to have improved specific mechanical properties in order to be used as structural components in aircraft in substitution to the regular ones, as the AA7050-T7451. As fatigue is a major concern in this type of application, the following conclusions were obtained:

- In the threshold region, in air and at RT it was found a $\Delta \mathrm{K}_{\mathrm{th}}=2.9 \mathrm{MPa} \cdot \mathrm{m}^{1 / 2}$ for AA2050-T84, in saline environment this value increased to $\Delta \mathrm{K}_{\text {th }}=4.9 \mathrm{MPa}$. $\mathrm{m}^{1 / 2}$. However, the effective value of the FCG threshold

\section{References}

1. ASM International. Properties and selection: nonferrous alloys and special-purpose materials. Materials Park; 1990. ASM Handbook, 2.

2. Sanders TH Jr and Starke EA Jr. Aluminum-lithium alloys. In: Proceedings of the Fifth International Aluminum-Lithium Alloys; 1980; Stone Mountain, GA. Warrendale: Metallurgical Society of AIME; 1981.

3. Sanders TH Jr and Starke EA Jr. Aluminum-lithium alloys II. In: Proceedings of the Second International Conference on Aluminum-Lithium Alloys II; 1983; Monterey, CA. Warrendale: Metallurgical Society of AIME; 1983.

4. Conde A, Fernández BJ and Damborenea JJ. Characterization of the SCC behavior of $8090 \mathrm{Al}-\mathrm{Li}$ alloy by means of the slowstrain-rate technique. Corrosion Science. 1995; 40(1):91-102. http://dx.doi.org/10.1016/S0010-938X(97)00117-0.

5. Devereux OF, McEvely AJ and Staehle RW. Corrosion fatigue: chemistry, mechanic, and microstructure. Part VII. Aluminum alloys. Houston: National Association of Corrosion Engineers; 1972. p. 451.

6. Menan F and Henaff G. Influence of frequency and exposure to a saline solution on the corrosion fatigue crack growth behavior of the aluminum alloy 2024. International Journal of Fatigue. 2009; 31(11-12):1684-1695. http://dx.doi.org/10.1016/j. ijfatigue.2009.02.033.

7. Suresh S. Fatigue of materials. 2nd ed. Cambridge: Cambridge University Press; 1998. p. 1-29.

8. Dowling NE. Mechanical behavior of materials: engineering methods for deformation fracture and fatigue. Englewood Cliffs: Prentice Hall; 1992. was quite similar to the one in air, $\Delta \mathrm{K}_{\text {eff }}=3.0 \mathrm{MPa} \cdot \mathrm{m}^{1 / 2}$. In this case, crack closure was due to intense formation of corrosion-products, inducing to wedge effect.

- At the beginning of the region II (Paris-Erdogan region), the crack closure effect was not present for the AA7050-T7451, but persisted for the AA2050 Al-li alloy. At higher $\Delta \mathrm{K}$ values, the environment has less time to interact with the propagating front and the FCG process occurs by almost purely mechanical action as the case in air, and the FCG rates are quite similar for both alloy and test conditions.

\section{Acknowledgements}

The authors would like to thanks CNPq, CAPES and FIPAI for the financial support, and the Department of Materials, São Carlos School of Engineering, University of São Paulo for the use of the experimental facilities.

9. Zhang R and Mahadevan S. Reliability-based reassessment of corrosion fatigue life. Structural Safety. 2001; 23(1):77-91. http://dx.doi.org/10.1016/S0167-4730(01)00002-9.

10. Alrubaie K, Barroso E and Godefroid L. Fatigue crack growth analysis of pre-strained 7475-t7351 aluminum alloys. International Journal of Fatigue. 2006; 28(8):934-942. http:// dx.doi.org/10.1016/j.ijfatigue.2005.09.008.

11. Robinson MJ and Jackson NC. The influence of grain structure and intergranular corrosion rate on exfoliation and stress corrosion cracking of high strength Al-Cu-Mg alloys. Corrosion Science. 1999; 41(5):1013-1028. http://dx.doi.org/10.1016/ S0010-938X(98)00171-1.

12. Hollingsworth EH and Hunsciker HY. Corrosion of aluminum and aluminum alloys. In: American Society for Metals. Metal Handbook. 9th ed. Ohio: ASM International; 1987. p. 83-609.

13. Lin C-K and Yang S-T. Corrosion fatigue behavior of 7050 aluminum alloys in different tempers. Engineering Fracture Mechanics. 1998; 59(6):779-795. http://dx.doi.org/10.1016/ S0013-7944(97)00173-2.

14. American Standard for Testing and Materials - ASTM. ASTM E647-11: standard test method for measurement of fatigue crack growth rates. West Conshohocken; 2010.

15. Maciel CIS. Estudo da tenacidade e fadiga em meio assistido da liga de Al-Li de grau aeronáutico AA2050-T84. [Thesis]. São Carlos: Escola de Engenharia de São Carlos da Universidade de São Paulo - EESC-USP; 2013.

16. Komai K. Corrosion fatigue. In: Ritchie RO and Murakami Y, editors. Comprehensive structural integrity: fracture of materials from nano to macro. Amsterdam: Elsevier; 2003. v. 4. p. 345358. http://dx.doi.org/10.1016/B0-08-043749-4/04091-X. 
17. Vasudévan AK and Suresh S. Influence of corrosion deposits on near: threshold fatigue crack growth behavior in 2XXX and 7XXX series aluminum alloys. Metallurgical Transactions A: Physical Metallurgy and Materials Science. 1982; 13(12):22712279. http://dx.doi.org/10.1007/BF02648397.

18. Ford FP. Quantitative examination of slip-dissolution and hydrogen-embrittlement theories of cracking in aluminium alloys. Materials Science and Technology. 1978; 12(7):326-334.

19. Albelkis PR. Low temperature and loading frequency effects on crack growth and fracture toughness of 2024 and 7475 aluminum. In: Stephen RI. Fatigue at low temperatures. Philadelphia: American Society for Testing and Materials; 1985. p. 257-273. ASTM Special Technical Publication, 857.

20. Zheng XL and Lu BT. Fatigue crack propagation in metals at low temperatures. In: Campinteri A. Hadbook of fatigue crack: propagation in metallic structures. Amsterdam: Elsevier Science; 1994.

21. Schijve J. Fatigue of structures and materials. Netherlands: Springer; 2001. 